\title{
nature
}

\section{Compromise on arms control?}

\section{Recent noises from the United States and the Soviet Union suggest that the prospect of a deal on arms control may be more immediate than it has seemed.}

More than usual confusion seems to mark the ending a week ago of the latest session of the bilateral talks on arms control at Geneva. On the face of things, President Reagan's declaration that the United States would not necessarily be bound by the SALT II agreement on strategic arms from the autumn of this year made the prospect of an agreement at Geneva less easily attainable than since the negotiations began. Yet Mr Mikhail Gorbachev, the general secretary of the Soviet Communist Party, appears to have sent Mr Reagan a conciliatory letter, coinciding with the summer break at Geneva, whose effect is to suggest that compromise is within the bounds of possibility on the control of weapons of intermediate range in Europe. What is going on? Were the Soviet Union's fierce reactions to $\mathrm{Mr}$ Reagan's announcement mere bluff? Or has the Soviet Union been told privately that it is Mr Reagan who was bluffing, and that his threat that SALT II might be abandoned was directed not so much at Moscow as at the hard-liners in Washington?

Enough has now leaked out about the conduct of the Geneva negotiations to sustain a degree of nervous optimism. Mr Gorbachev's message bears on one stumbling block: how to legislate for the complete banning of intermediate-range missiles (SS20 Soviet missiles and the Pershing II and cruise missiles deployed in Europe by the United States) while recognizing that SS20s could be quickly moved from Asia, that the British and French nuclear forces exist and that both sides also have a large number of shorter-range weapons which, if the major Soviet and US missiles were withdrawn, would acquire a strategic significance they now lack? Both sides at Geneva appear to have been captivated by the notion that it would be simplest to do away with all missiles of intermediate range (which, Mr Reagan's "zero option" of 1982, is progress in itself). Mr Gorbachev's suggestion now that compromise is possible suggests the possibility of an agreement on the basis of a sharply reduced but nonzero intermediate force. Few would complain at that.

Much less has been said about progress at Geneva on strategic arms. It would help, of course, if the two sides were merely to agree to limit strategic weapons to the numbers allowed under SALT II (a gigantic 5,000 warheads each) and were to take the opportunity to tidy up the treaty, making it acceptable to the US Congress, but that will not satisfy the aspirations of the rest of the world, while even the negotiators at Geneva appear to think that would be a prize not worth having (which, again, is progress of a kind). The best bet is that a fifty per cent reduction of warheads is attainable now; Mr Gorbachev made an important mark earlier this year with his declaration that even such an agreement could be only an interim measure, a prelude to further more substantial reductions of nuclear arms. The paradox is that, if that principle were accepted by both sides, the degree of reduction agreed in the next few months would be less important, and so would be more easily attained.

The third item on the agenda at Geneva is the most taxing, and that most likely to prevent an agreement being reached: to what extent will the devotion of the US administration to the Strategic Defense Initiative (SDI) stick in the throat of the Soviet Union? Here too, Mr Gorbachev has been making conciliatory noises: if research means only laboratory research, all well and good. But then. Mr Gorbachev continues (as in his latest letter to Mr Reagan) why should not both sides reaffirm their adherence to the Anti-Ballistic Missile Treaty, undertaking that they will not quit the treaty for. say, 15 years? This position represents a Soviet retreat from the fierce declarations from Moscow in 1983, suggesting that merely toying with the idea of a defence against ballistic missiles was an act of aggression. But it seems improbable that Mr Gorbachev's moderation of the past few weeks suggest he will to let SDI go ahead full tilt.

Fortunately, even here constructive compromises should be possible. First, Mr Gorbachev probably knows as well as anybody of the reluctance of the US Congress to give the project the huge sums of money it has been asking for, implying that decisions about the deployment of SDI will not take place until long after the promised decision time in the early 199()s. Second. it is also well known that there has to be a general election in the United States two years from now. and that a new president $\mathrm{Mr}$ Reagan cannot stand for a third term). whatever his or her political stripe, may not set as much store by the benefits of SDI. Finally. however meagre the outlook for this ambitious project. there is no obvious reason why the most likely outcome of this system, an efficient system of early warning based on infrared detectors, should not be welcomed by both sides. That is one sense in which Mr Gorbachev's suggestion that both sides should reaffirm the ABM treaty for 15 years is already a useful compromise. It requires from the United States only that degree of restraint likely to be forced on it by the technological difficulties of this ambitious project and by the increasing scepticism of the US Congress; if the two sides can make some kind of agreement this year, Congress will be even less willing to spend, with the result that the dangerous features of SDI will wither away.

So much for the carrots: Mr Gorbachev's stick is the threat that he will not attend a second summit meeting unless there is something substantial about which to agree. Once the summer is over, and the campaign for the mid-term elections has begun. there will be powerful forces in the United States pushing the administration towards some lasting achievement on the international front. To fail to have a summit meeting will seem. or be made to seem, a black mark in the first week in November. Not for the first time. Mr Reagan may find that his natural (and evidently deeply felt) suspicion of arms control agreements will have to be forsaken in the face of the general feeling that there is no more laudable goal. This is the turnabout forced on him during the first vear of his administration six years ago.

\section{Research democracy}

Moving Greenwich to Cambridge is not the end of the world, but users' voices need to be heard.

How should grant-making agencies manage their relations with those parts of the research community that rely on them for support? That is the question most urgently prompted by the decision of the British Science and Engineering Research Council (SERC) last week that the Royal Greenwich Observatory (RGO) should be moved to Cambridge rather than to 